\title{
Groundwater quality appraisal and its hydrochemical characterization in Ghaziabad (a region of indo-gangetic plain), Uttar Pradesh, India
}

\author{
Uday Veer Singh • Amar Abhishek • \\ Kunwar P. Singh · Ratnakar Dhakate • \\ Netra Pal Singh
}

Received: 20 February 2013/Accepted: 24 October 2013/Published online: 9 November 2013

(C) The Author(s) 2013. This article is published with open access at Springerlink.com

\begin{abstract}
India's growing population enhances great pressure on groundwater resources. The Ghaziabad region is located in the northern Indo-Gangetic alluvium plain of India. Increased population and industrial activities make it imperative to appraise the quality of groundwater system to ensure long-term sustainability of resources. A total number of 250 groundwater samples were collected in two different seasons, viz., pre-monsoon and post monsoon and analyzed for major physico-chemical parameters. Broad range and great standard deviation occurs for most parameters, indicating chemical composition of groundwater affected by process, including water-rock interaction
\end{abstract}

U. V. Singh $\cdot$ K. P. Singh

Environmental Chemistry Division, CSIR-Indian Institute of

Toxicology Research (Council of Scientific and Industrial

Research), Mahatma Gandhi Marg, Post Box 80,

Lucknow 226 001, India

\section{A. Abhishek}

Environmental Microbiology Section, CSIR-Indian Institute of

Toxicology Research (Council of Scientific and Industrial

Research), Mahatma Gandhi Marg, Post Box 80,

Lucknow 226 001, India

R. Dhakate

Department of Environmental Geophysics,

CSIR-National Geophysical Research Institute,

Uppal Road, Hyderabad 500007, India

\section{N. P. Singh $(\bowtie)$}

Bioinorganic Chemistry Division, Department of Chemistry,

Meerut College, Meerut, India

e-mail: netrapal_singh@yahoo.com

\section{N. P. Singh}

Department of Chemistry, Shri Jagdish Prasad Jhabarmal

Tibrewala University, Vidyanagari, Jhunjhunu,

Rajasthan 333001, India and anthropogenic effect. Iron was found as predominant heavy metal in groundwater samples followed by copper and lead. An exceptional high concentration of Chromium was found in some locations. Industrial activities as chrome plating and wood preservative are the key source to metal pollution in Ghaziabad region. On the basis of classification the area water shows normal sulfate, chloride and bicarbonate type, respectively. Base-exchange indices classified $76 \%$ of the groundwater sources was the sodiumbicarbonate type. The meteoric genesis indices demonstrated that $80 \%$ of groundwater sources belong to a shallow meteoric water percolation type. Chadha's diagram suggested that the hydro-chemical faces belong to the $\mathrm{HCO}_{3}{ }^{-}$dominant $\mathrm{Ca}^{2+}-\mathrm{Mg}^{2+}$ type along with $\mathrm{Cl}^{-}$-dominant $\mathrm{Ca}^{2+}-\mathrm{Mg}^{2+}$-type. There was no significant change in pollution parameters in the selected seasons. Comparison of groundwater quality with Indian standards proves that majority of water samples are suitable for irrigation purposes but not for drinking.

Keywords Groundwater - Base exchange indices . Meteoric genesis indices - Salinity index ·

Chadda's diagram · Sodacity index

\section{Introduction}

Groundwater is an important natural reservoir of our environment and for this reason cannot be looked upon in isolation. The Indo-gangetic plain is the largest alluvial plain in the world and was formed by deposition of terrigenous clastic sediments from streams of the Indus, Ganga, and Brahmaputra river systems (Ansari et al. 2000). The aquifer in this plain is under severe environmental pressure due to urbanization, rapid agricultural growth, and 
industrial development. Ghaziabad city lies in the upper Indo-Gangetic plain of north east India. In this region, "self supply" and "vulnerability" are directly coupled. Moreover, there has been also a lack of adequate attention to water use, water re-use, and recharge of groundwater. Over the year, this region which runs through the most industrialized zone of northern India, having various types of industries dealing mainly with iron, steel, plastic, dyeing, chemical, pharmaceutical, battery making, etc., which dispose their treated or partially treated effluents indiscriminately causing a wide range of heavy metal contamination (Kumari et al. 2013).

The quality of water is vital owing to its appropriateness for a range of purposes since it is directly coupled with human welfare. Groundwater quality variation is a function of physico-chemical patterns in an area influenced by geological and anthropogenic activities (Subramani et al. 2005). To determine the origin of chemical composition of groundwater, there is a need of actual knowledge of hydrochemistry, which lead to a number of detailed studies on groundwater quality deterioration and geochemical evolution of groundwater in different parts of India as well as globe (Jalali 2006, 2007; Gupta et al. 2008; Irfan and Said 2008; Kumar et al. 2009; Srinivasamoorthy et al. 2010; Zhang et al. 2011; Vasanthavigar et al. 2012). Increased knowledge of geochemical processes regulating the groundwater chemical composition will lead to understand the hydrochemical systems for effective management and utilization of the groundwater resources by clarify relations among groundwater quality and quantifying any future quality changes. The hydrochemistry of groundwater in Ghaziabad region is inadequate because most of the studies focused on a few regions of Ghaziabad (Kumari et al. 2013) with low sample size. Moreover, groundwater and its suitability for drinking and agricultural rational have not been endeavored in the present study area dominantly; hence an effort has been made in here to exemplify anthropogenic influences on groundwater chemistry selecting a huge sample size, which represents the actual picture of study area.

\section{Study area}

Ghaziabad is a planned industrial city along the Grand Trunk road $\sim 2.5 \mathrm{~km}$ from the Hindon River between $28^{\circ} 40^{\prime}$ and $28^{\circ} 67^{\prime} \mathrm{N}$ (latitude) and $77^{\circ} 25^{\prime}$ and $77^{\circ} 42^{\prime} \mathrm{E}$ (longitude) (Fig. 1). Ghaziabad densely populated, has many industries in surrounding areas that use high rate of chemicals, fertilizers/pesticides. Ghaziabad houses are one of the largest and most modern electric locomotive sheds. Urban and industrial waste disposal sites exist in the region due to the close vicinity of Delhi and several big townships.

\section{Geology}

The rock type exposed in the study area belongs to lower Proterozoic age and consists of Quartzite and Phyllite. The Quartzites are massive, thickly bedded, hard, compact and highly jointed and they are intercalated with thin beds of Phyllite and Slates. These rocks are mostly covered by quaternary sediments and are exposed in isolated residual and structural hills and pediments. Geologically the town forms the part of Indo-Gangetic alluvium, which consist of sand, clay, Kankar and reh. In the city, the strata consists mainly of sandy soil. The soil is quite fertile and loamy. The depth of sub-soil water table in this area is about $10-15 \mathrm{~m}$ below ground level and the seasonal variation is about $5 \mathrm{~m}$. Ghaziabad is situated in an agricultural area of western UP.

\section{Aquifer context}

On the basis of exploratory drilling carried out in the area three tier aquifer systems has been identified down to a depth of $450 \mathrm{mbgl}$. The first aquifer system extends down to a depth of $125 \mathrm{mbgl}$ and it extends down to $200 \mathrm{mbgl}$ in north part of the district. Thickness of aquifer decreases in the western part of the district and depth of bedrock is shallow. Second aquifer system exists in the depth range $170-350 \mathrm{mbgl}$. The aquifer is medium- to fine-grained sand with occasional coarse-grained sand. The third aquifer system occurs below $350 \mathrm{~m}$ and continues down to depth explored of $450 \mathrm{~m}$ (Sinha 1980).

\section{Methodology}

Sampling strategy

A total number of 250 groundwater samples (shallow and deep bore hand-pumps, India Mark-II) were collected from the study area. 125 samples were collected during premonsoon (PRE-M) (May, 2011) and the same number were collected during post-monsoon (POST-M) (November, 2011) season. The groundwater samples were collected from hand-pump after flushing water for $10-15 \mathrm{~min}$. The samples were collected in new pre-washed 1:1 HDPE bottles with dilute hydrochloric acid and rinsed 3-4 times with distilled water and dried before use. The water samples for heavy metal analysis were collected in $500 \mathrm{~mL}$ acid washed polyethylene bottles preserved by nitric acid addition at the site $(\mathrm{pH}<2)$. All the samples were immediately transported to the laboratory under low temperature conditions in ice-boxes. The samples were stored in the laboratory at $4{ }^{\circ} \mathrm{C}$ until processed/analyzed. For 


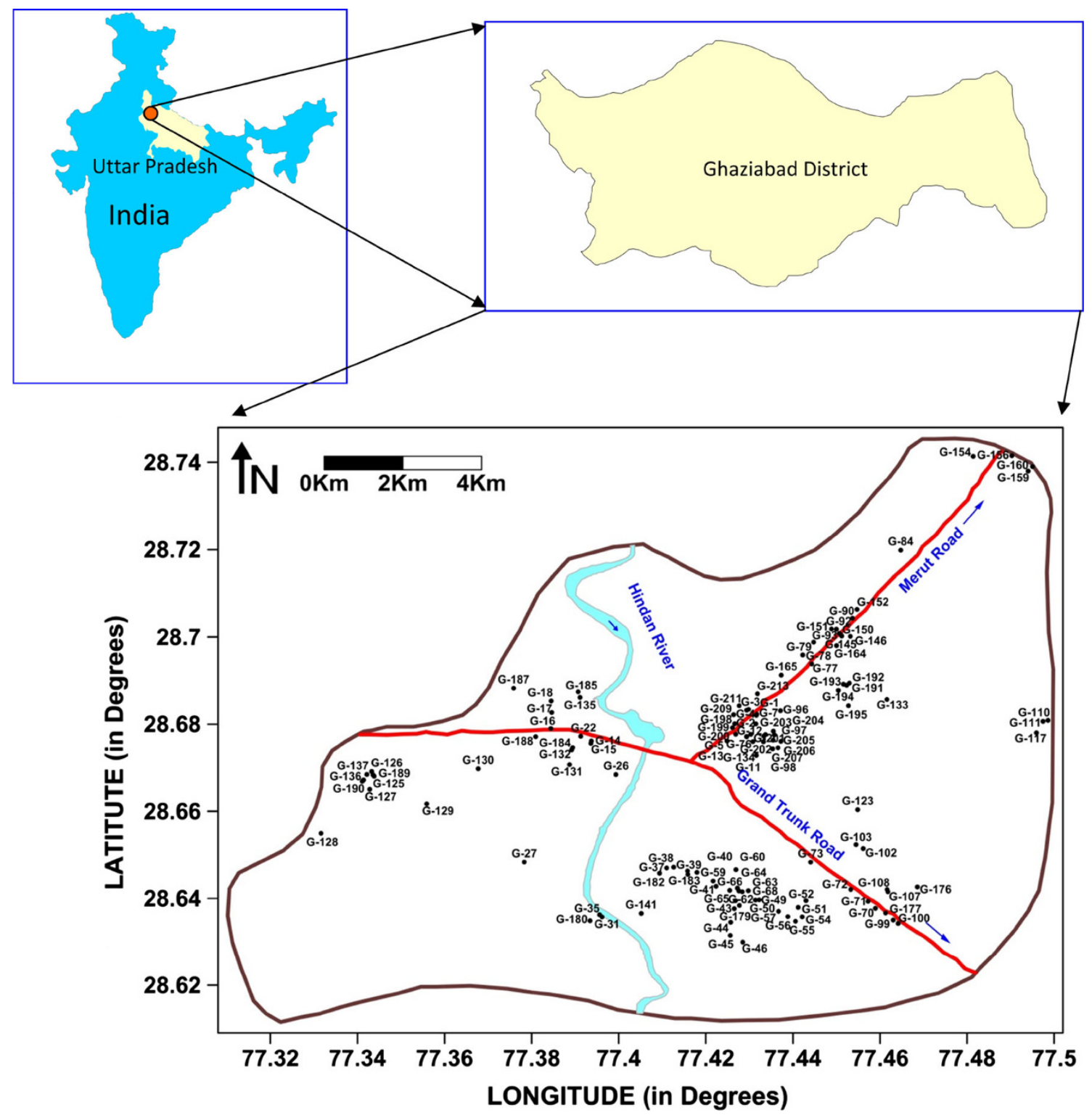

Fig. 1 Site location map of study area

collection, preservation and analysis of the samples, the standard analytical procedures as recommended by the American Public Health Association (APHA) (2005) were employed.

\section{Analytical procedures}

The groundwater samples were analyzed for $\mathrm{pH}$, electrical conductivity (EC), salinity, total alkalinity (TA), total dissolve solid (TDS), total hardness (TH), ammonical form of nitrogen, silica $\left(\mathrm{SiO}_{2}\right)$. The main anions like carbonate $\left(\mathrm{CO}_{3}{ }^{2-}\right)$, bi-carbonate $\left(\mathrm{HCO}_{3}{ }^{-}\right)$, nitrite $\left(\mathrm{NO}_{2}{ }^{2-}\right)$, nitrate $\left(\mathrm{NO}_{3}{ }^{-}\right)$, sulfate $\left(\mathrm{SO}_{4}{ }^{2-}\right)$, phosphate $\left(\mathrm{PO}_{4}{ }^{3-}\right)$, chloride $\left(\mathrm{Cl}^{-}\right)$, bromide $\left(\mathrm{Br}^{-}\right)$as well as important cations like sodium $\left(\mathrm{Na}^{+}\right)$, potassium $\left(\mathrm{K}^{+}\right)$, magnesium $\left(\mathrm{Mg}^{2+}\right)$, and calcium $\left(\mathrm{Ca}^{2+}\right)$, and heavy metals like chromium $(\mathrm{Cr})$, copper $(\mathrm{Cu})$, iron $(\mathrm{Fe})$, and lead $(\mathrm{Pb})$ were analyzed. Water temperature was measured on the site using mercury thermometer while other parameters were determined in laboratory within $48-72 \mathrm{~h}$ of the sampling following the standard methods (APHA 2005).

EC, pH, salinity, chloride $\left(\mathrm{Cl}^{-}\right)$, fluoride $\left(\mathrm{F}^{-}\right)$, and nitrate $\left(\mathrm{NO}_{3}{ }^{-}\right)$were analyzed using multiple parameters ion meter model Thermo Orion 5 Star. Sulfate $\left(\mathrm{SO}_{4}{ }^{2-}\right)$, phosphate $\left(\mathrm{PO}_{4}{ }^{3-}\right)$, and silica $\left(\mathrm{SiO}_{2}\right)$ were measured using a double beam UV-Vis spectrophotometer model Perkin Elmer Lambda 35 by turbidimetric, stannous chloride, and molybdosilicate, respectively. Sodium $\left(\mathrm{Na}^{+}\right)$, potassium $\left(\mathrm{K}^{+}\right)$, calcium $\left(\mathrm{Ca}^{2+}\right)$, and magnesium $\left(\mathrm{Mg}^{2+}\right)$ were 
analyzed using flame photometer model CL-378 (Elico, India). Total hardness was determined by EDTA titrimetric method. TDS were measured gravimetrically. Total carbonate and bicarbonate alkalinities were measured by acidbase titration. The heavy metals, chromium (Cr), copper $(\mathrm{Cu})$, iron $(\mathrm{Fe})$, and lead $(\mathrm{Pb})$ were measured using Ultima inductively coupled plasma spectrometer in the acid digested samples. The digestion was carried out with nitric/ perchloric acid mixture (5:1). The analytical data quality was ensured through careful standardization, procedural blank measurements and duplicate samples. The ionic charge balance of each sample was within $\pm 5 \%$. The laboratory also participates in regular national program on analytical quality control. Precision and accuracy of the metal analysis data were ensured through repeated analysis $(n=11)$ of National Bureau of Standards No. $42 \mathrm{G}$ for the metals and the results were found within $\pm 2 \%$ of the certified values. Quantification of the metals was based on calibration curves of standard solution of metals (Merck, India). The precision of the analytical procedures expressed as the relative standard deviation (RSD) range from 5 to
$10 \%$. In all the analysis, blanks were run and corrections were applied, if necessary. All observations were recorded in duplicate and average values are reported.

\section{Results and discussion}

Physico-chemical characterization of groundwater

The physicochemical parameters were analyzed statistically, and results are given in Table 1. Broad range and great standard deviation occurs for most parameters, indicating chemical composition of groundwater affected by process, including water-rock interaction and anthropogenic effect. The $\mathrm{pH}$ value varies from 6.82 to 8.40 during PRE-M and 6.85 to 8.44 during POST-M season's indication slightly acidic to alkaline nature of groundwater of the region; arise due to the leaching of dissolved constituents into the groundwater. The EC values during PRE-M and POST-M range from 191.6 to 5,260.0 $\mu \mathrm{S} / \mathrm{cm}$ and 599.0 to $5,040.0 \mu \mathrm{S} / \mathrm{cm}$ with an average of $1,803.4$ and
Table 1 Physico-chemical characteristics of groundwater samples
All the parameters in $\mathrm{mg} / \mathrm{L}$ except $\mathrm{pH}$, conductivity, and salinity

$S D$ standard deviation, $B D L$ below detection limit, $T D S$ total dissolve solid, $T H$ total hardness, $T A$ total alkalinity

\begin{tabular}{|c|c|c|c|c|}
\hline \multirow[t]{2}{*}{ Variables } & \multicolumn{2}{|l|}{ Pre-monsoon } & \multicolumn{2}{|l|}{ Post-monsoon } \\
\hline & Range & Mean \pm SD & Range & Mean \pm SD \\
\hline $\mathrm{pH}$ & $6.8-8.4$ & $7.3 \pm 0.34$ & $6.8-8.4$ & $7.5 \pm 0.3$ \\
\hline $\mathrm{EC}(\mu \mathrm{S} / \mathrm{cm})$ & $191.6-5,260.0$ & $1,803.4 \pm 910.8$ & $599.0-5,040.0$ & $1,535.5 \pm 786.8$ \\
\hline Salinity (ppt) & $0.3-2.4$ & $0.8 \pm 0.4$ & $0.3-2.8$ & $0.8 \pm 0.4$ \\
\hline TDS & $369.0-3,470.0$ & $1,198.8 \pm 597.2$ & $396.0-33,340.0$ & $1,268.2 \pm 2,938.8$ \\
\hline TH & $76.0-2,480.0$ & $406.6 \pm 288.5$ & $132.0-1,560.0$ & $362.8 \pm 197.8$ \\
\hline TA & $140.0-600.0$ & $305.9 \pm 96.1$ & $76.6-624.0$ & $321.3 \pm 119.9$ \\
\hline $\mathrm{Na}^{+}$ & $29.1-1,896.0$ & $368.1 \pm 307.8$ & $23.5-850.0$ & $198.7 \pm 130.5$ \\
\hline $\mathrm{K}^{+}$ & $4.4-27.6$ & $9.8 \pm 2.9$ & $4.3-35.8$ & $10.9 \pm 4.0$ \\
\hline $\mathrm{Ca}^{2+}$ & $8.0-128.0$ & $36.9 \pm 23.3$ & $3.2-304.0$ & $59.9 \pm 45.3$ \\
\hline $\mathrm{Cl}^{-}$ & $15.9-1,252.8$ & $275.4 \pm 274.8$ & $19.8-2,953.7$ & $386.5 \pm 482.4$ \\
\hline $\mathrm{Mg}^{2+}$ & $5.76-556.8$ & $75.4 \pm 63.1$ & $4.8-361.9$ & $51.1 \pm 41.7$ \\
\hline $\mathrm{CO}_{3}{ }^{2-}$ & BDL-240.0 & $41.9 \pm 34.4$ & BDL-120.0 & $49.9 \pm 29.0$ \\
\hline $\mathrm{HCO}_{3}^{-}$ & $60.0-560.0$ & $264.1 \pm 105.4$ & $52.0-520.0$ & $271.4 \pm 106.8$ \\
\hline Silica & $1.4-31.6$ & $20.4 \pm 3.9$ & $14.3-51.3$ & $26.5 \pm 4.9$ \\
\hline Ammonical form of $\mathrm{N}_{2}$ & BDL-51.0 & $1.6 \pm 5.8$ & BDL-69.0 & $1.9 \pm 7.2$ \\
\hline $\mathrm{NO}_{2}^{-}$ & BDL-4.2 & $0.3 \pm 0.7$ & $0.01-11.9$ & $0.4 \pm 1.3$ \\
\hline $\mathrm{SO}_{4}{ }^{2-}$ & $7.3-1,366.0$ & $100.6 \pm 187.1$ & $6.8-1,376.0$ & $139.9 \pm 204.9$ \\
\hline $\mathrm{PO}_{4}^{3-}$ & BDL-0.5 & $0.03 \pm 0.1$ & BDL-1.2 & $0.05 \pm 0.2$ \\
\hline $\mathrm{Br}^{-}$ & BDL-2.8 & $0.76 \pm 0.49$ & BDL-2.9 & $0.83 \pm 0.53$ \\
\hline $\mathrm{F}^{-}$ & $0.12-8.1$ & $0.82 \pm 0.81$ & $0.09-10.9$ & $0.70 \pm 1.0$ \\
\hline $\mathrm{NO}_{3}^{-}$ & $0.4-60.7$ & $5.9 \pm 9.7$ & $0.42-46.5$ & $4.8 \pm 7.6$ \\
\hline \multicolumn{5}{|l|}{ Heavy metals } \\
\hline $\mathrm{Cr}$ & BDL-35.8 & $0.54 \pm 3.7$ & BDL-69.4 & $1.1 \pm 7.4$ \\
\hline $\mathrm{Cu}$ & BDL-0.23 & $0.01 \pm 0.03$ & BDL-0.17 & $0.01 \pm 0.02$ \\
\hline $\mathrm{Fe}$ & BDL-8.3 & $0.64 \pm 1.21$ & BDL-21.8 & $1.8 \pm 2.9$ \\
\hline $\mathrm{Pb}$ & BDL-0.13 & $0.01 \pm 0.02$ & BDL-0.09 & $0.01 \pm 0.02$ \\
\hline
\end{tabular}


1,535.5 $\mu \mathrm{S} / \mathrm{cm}$ (Table 1). EC exceeds the Bureau of Indian Standard (BIS) permissible limit $(>1,000 \mu \mathrm{S} / \mathrm{cm})$ in $\sim 82$ and $75 \%$ in PRE-M and POST-M samples, respectively.

In natural waters, dissolved solids mainly consist of inorganic salts such as carbonates bicarbonates, chlorides, sulfates, phosphates and nitrates of calcium, magnesium, sodium, potassium, iron, etc., and having a small amount of organic matter and dissolver gases. High values of TDS suggest the hydrolysis of sodium or potassium silicate as a countable factor in the chemistry of groundwater (Chae et al. 2006). Water containing more than $500 \mathrm{mg} / \mathrm{L}$ of TDS if used for drinking purposes may induce an unfavorable physiological reaction in the transient consumer and gastrointestinal infections (Dar et al. 2011).

Water alkalinity reflected to as the acid neutralizing capacity of the water and arises due to the presence of bicarbonate $\left[\mathrm{HCO}_{3}{ }^{-}\right]$, carbonate $\left[\mathrm{CO}_{3}{ }^{2-}\right]$, and hydroxide ions $\left[\mathrm{OH}^{-}\right]$in the aquifer system. Total alkalinity values vary from 140.0 to $600.0 \mathrm{mg} / \mathrm{L}$ during PRE-M and 76.57 to $624.0 \mathrm{mg} / \mathrm{L}$ during the POST-M seasons (Table 1). According to BIS (2005) guideline; the desirable limit of alkalinity is $200 \mathrm{mg} / \mathrm{L}$. Higher values $(>200 \mathrm{mg} / \mathrm{L})$ noticed in 86.4 and $83.20 \%$ samples during PRE-M and POST-M season. Being the abundant anions in the groundwater and its dissolution into the groundwater is mainly due to the dissolution of silicates and rock weathering during the monsoon. Contribution is also made by the atmospheric $\mathrm{CO}_{2}$ along with $\mathrm{CO}_{2}$ released from the organic decomposition in the soil (Subba 2002). Total hardness is caused primarily due to the polyvalent ions (mainly calcium and magnesium). The total hardness ranges between 76.0 and $2,480.0 \mathrm{mg} / \mathrm{L}$ during PRE-M and 132.0 and 1,560.0 mg/L during POST-M periods. The high amount of hardness in the study area samples is due to the presence of carbonate rocks genuinely.

The concentration of calcium during PRE-M and POST$\mathrm{M}$ in the groundwater varies from 8.0 to 128.0 and 3.20 to
Fig. 2 Spatial distribution of Iron $(\mathrm{mg} / \mathrm{L})$, in the region during (a) pre-monsoon and (b) post-monsoon seasons
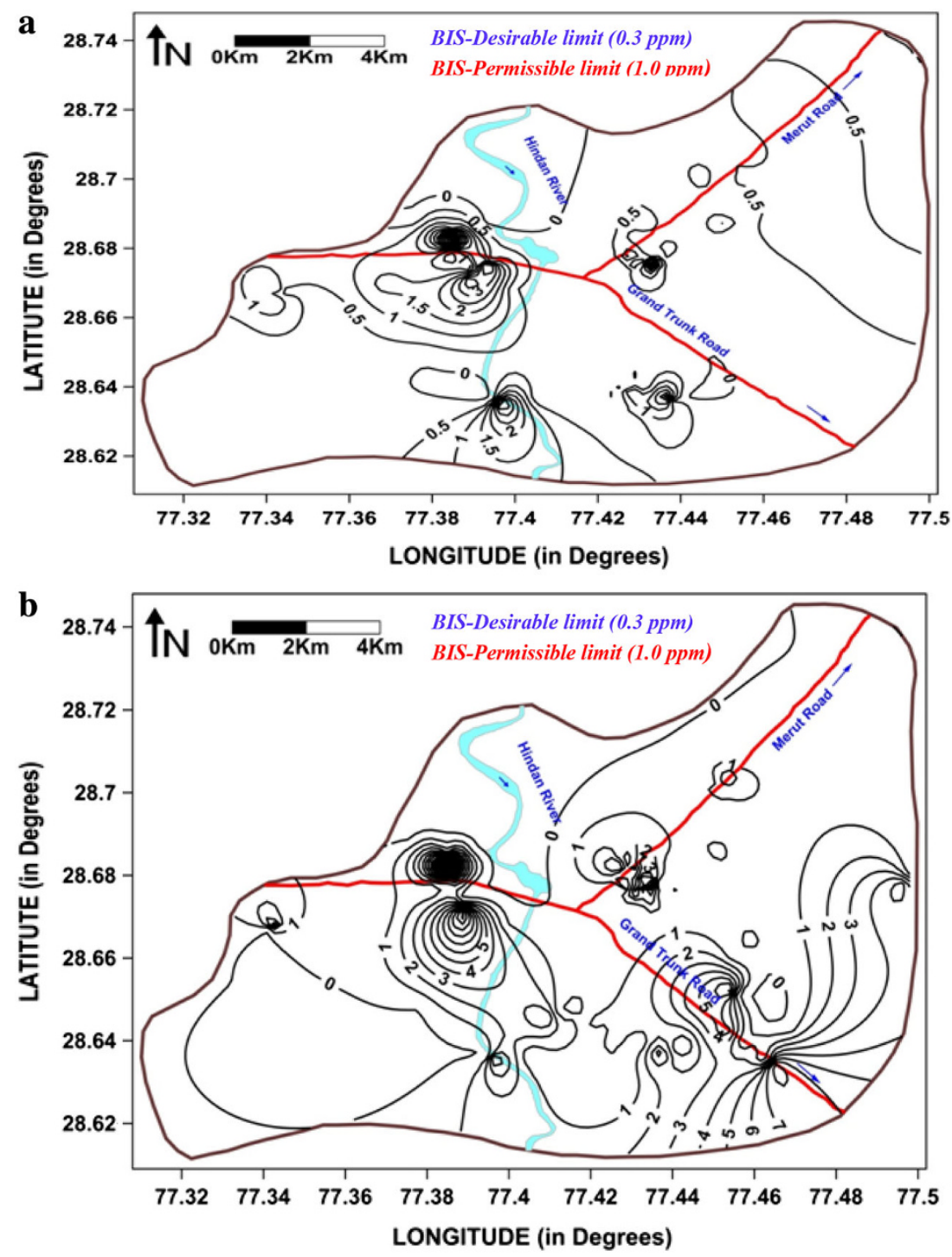

SACST Springer 
$304.0 \mathrm{mg} / \mathrm{L}$. Magnesium content varies from 5.76 to 556.80 and 4.80 to $361.92 \mathrm{mg} / \mathrm{L}$, during PRE-M and POST-M seasons. The alkali earth metals vary from 29.10 to 1,896 and 23.50 to $850 \mathrm{mg} / \mathrm{L}$ for sodium and 4.40 to 27.60 and 4.30 to $35.80 \mathrm{mg} / \mathrm{L}$ for potassium during PRE-M and POST-M seasons, respectively. The $73 \%$ groundwater samples during PRE-M and $41 \%$ samples during POST-M season exceed the permissible limit of $200 \mathrm{mg} / \mathrm{L}$ set for sodium (WHO 2004). The sources of potassium in groundwater include rain water, weathering of potash silicate minerals and application of potash fertilizer. It is more abundant in sedimentary rock and usually present in feldspar, mica and other clay minerals (Kolahchi and Jalali 2006). The higher concentrations of these cations in the groundwater might be due to their mineralogical origin in the soil. Besides above, the cation-exchange process, agricultural and industrial activities are also responsible for the high content of sodium and potassium in the study area.

Chloride occurs naturally in all type of waters. Chloride concentration varies from 15.86 to $1,252.83$ and 19.82 to 2,953.66 mg/L during PRE-M and POST-M seasons (Table 1). About 3.2 and $7.2 \%$ samples exceeds the permissible limit (1,000 mg/L; BIS 2005) during PRE-M and POST-M season, respectively. Chloride released in groundwater system through various physicochemical reactions like ion exchange. No adverse health effects on human being have been reported by the use of water having higher concentration of chloride. The sulfate concentration in the groundwater generally present as calcium, magnesium and sodium soluble salts. Sulfate content varies from 7.30 to $1,366 \mathrm{mg} / \mathrm{L}$ during PRE-M and 6.80 to $1,376 \mathrm{mg} / \mathrm{L}$ during POST-M seasons. Sulfate ion in the study area
Fig. 3 Spatial distribution of Copper $(\mathrm{mg} / \mathrm{L})$, in the region during (a) pre-monsoon and (b) post-monsoon seasons

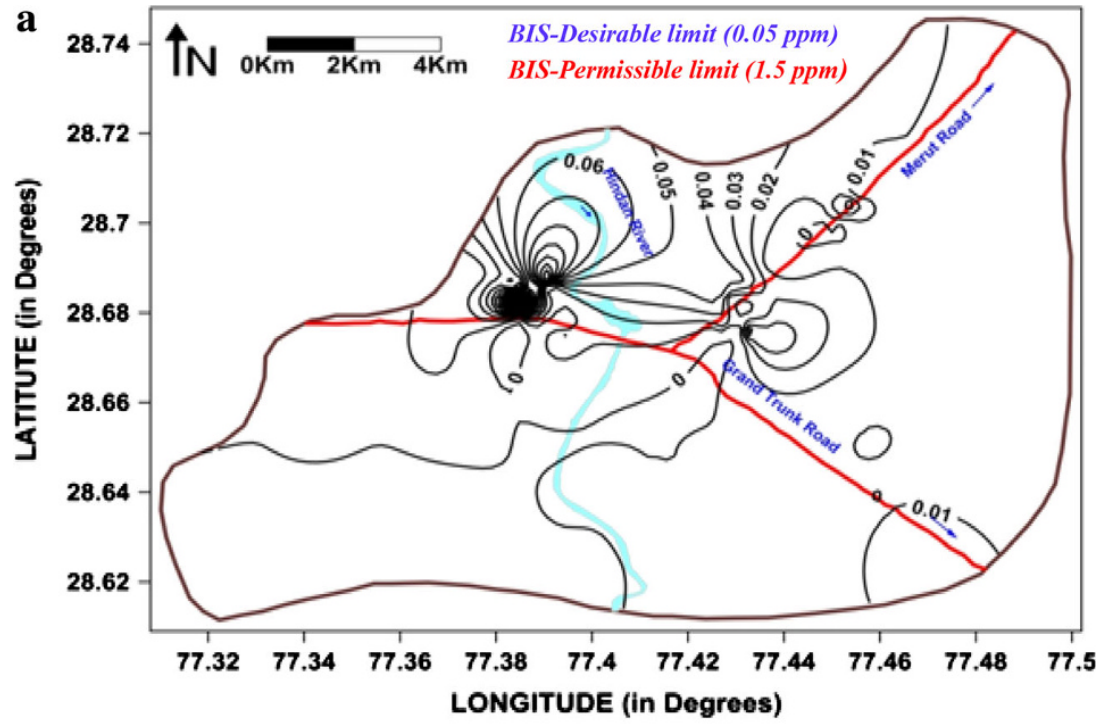

b

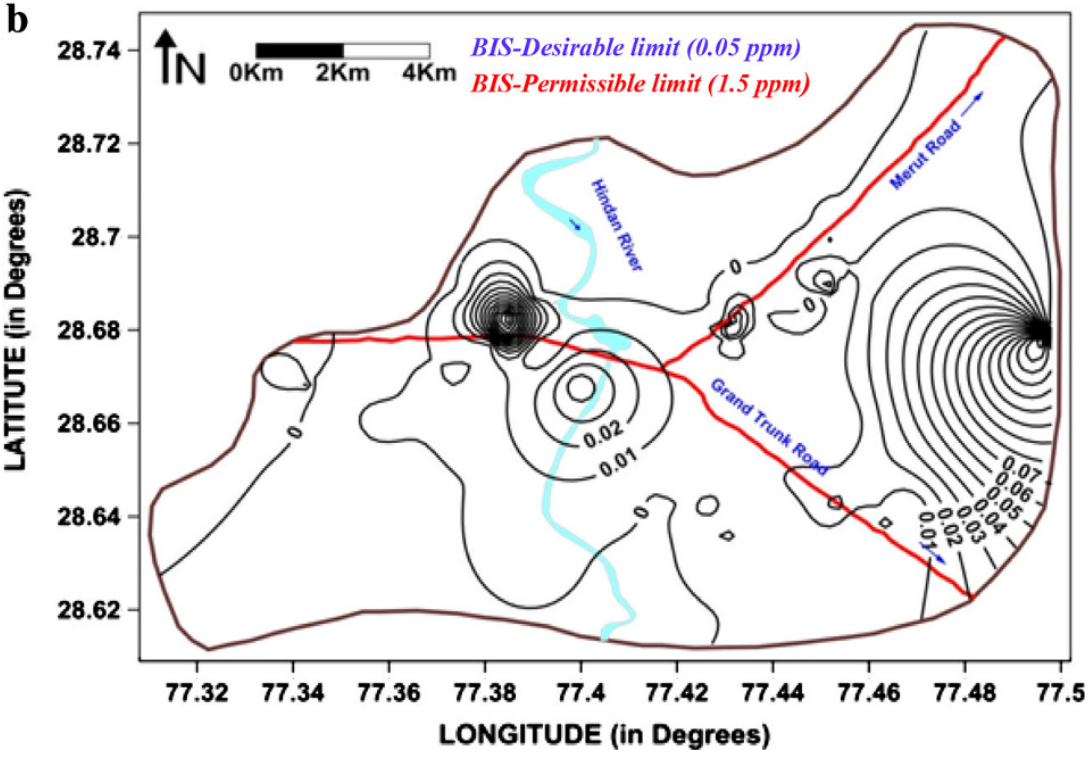


reveals that about $10 \%$ samples exceed the desirable limit and $6 \%$ sample violating the permissible limit of Bureau of Indian standard (BIS) (2005). These values were found to increase in POST-M, as $12 \%$ samples for desirable and $7.2 \%$ for permissible limit. Sulfate content changes significantly with time during rainfall infiltration and groundwater recharge, which mostly takes place from stagnant water body and surface runoff water accumulated in low lying areas (Singh 1994).

The nitrate concentration in the groundwater samples of the study area varies from 0.35 to 60.71 and 0.42 to $46.50 \mathrm{mg} / \mathrm{L}$ in PRE-M and POST-M. An abnormal concentration [ $>45 \mathrm{mg} / \mathrm{L}$ permissible limit; Bureau of Indian standard (BIS) 2005] was noted in location number G129 dominated by sewage line. However, none of the samples were found to go beyond the desirable as well as permissible limits of phosphate [Bureau of Indian standard (BIS)
2005]. High fluoride concentration in groundwater above the permissible limit has been major toxicological and geoenvironmental problem in India. Fluoride concentration in PRE-M and POST-M season exceeds the desirable limit $(1.0 \mathrm{mg} / \mathrm{L})$ (Bureau of Indian standard (BIS) 2005) at 31.20 and $20.8 \%$, respectively. At few locations, fluoride concentration exceeds the maximum permissible limit of $1.5 \mathrm{mg} / \mathrm{L}$ during both the seasons $(6.4,4.0 \%$ in PRE-M and POST-M season). Considerable amount of fluorides may be contributed due to anthropogenic activities (Ravikumar et al. 2013).

Heavy metals viz., cobalt and copper are extremely essential to humans, but if present in large quantities may cause physiological disorders. Cadmium, chromium, and lead are highly toxic even in trace concentration (Singh et al. 2013). The distribution of metal in the study region is shown in Figs. 2, 3, 4. The portability of groundwater is
Fig. 4 Spatial distribution of Lead $(\mathrm{mg} / \mathrm{L})$, in the region during (a) pre-monsoon and (b) post-monsoon seasons
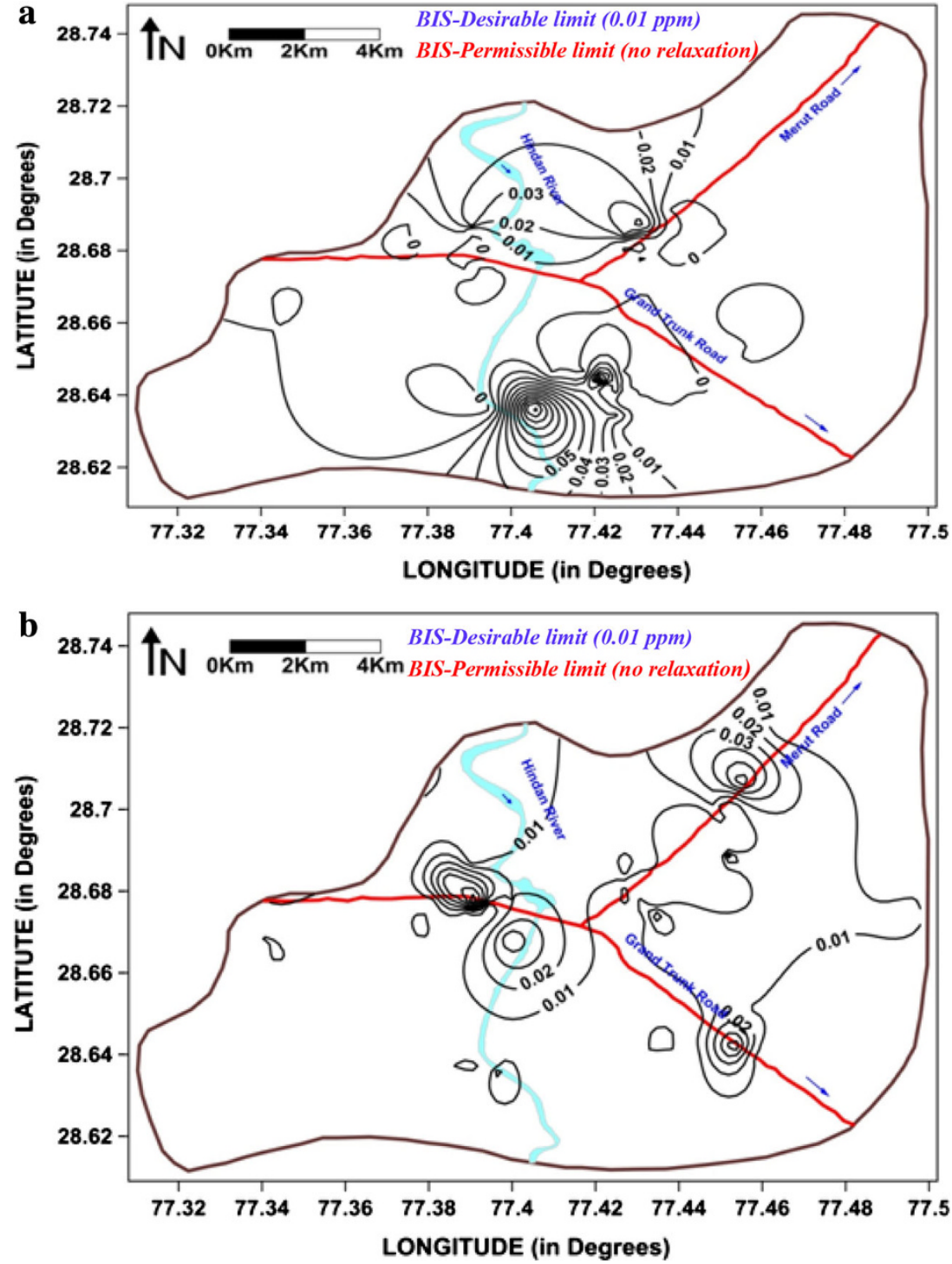

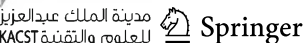


compared with the standard values (desirable and permissible limits) prescribed by Bureau of Indian standard (BIS) (2005). Iron is a predominant metal in groundwater sample ranging from 0.0 to $8.2 \mathrm{mg} / \mathrm{L}$ followed by copper and lead. Heavy metals $(\mathrm{Fe}, \mathrm{Cr}, \mathrm{Cu}$, and $\mathrm{Pb})$ are exceeding their respective desirable limits as prescribed by BIS for drinking water (Bureau of Indian standard (BIS) 2005). Moreover, iron exceeds the BIS desirable limit in $\sim 41$ and $70 \%$ samples of PRE-M and POST-M, respectively. This water should be treated for iron remediation prior to be consumed for domestic purposes. High iron concentrations cause an inky flavor, turbidity, bitter, and astringent taste. Water having soluble iron remains clear while pumped out. Exposure to air causes precipitation of iron resulting in rusty color and turbidity. High iron concentrations in these aquifers may be due to the interaction of oxidized Febearing minerals, organic matter and subsequent dissolution of $\mathrm{Fe}_{2} \mathrm{CO}_{3}$. Another possibility is that dissolved oxygen removal by organic matter produces reduced conditions, thereby increasing the solubility of Fe-bearing minerals (Pattanayak et al. 2000). The high iron concentration in the groundwater may also be due to the rusting of pipes and/or some localized effects. In the study area, some locations (coded as G1, G2, G7, G92, G93, G150, and G164) were found having chromium concentration exceptionally high $(>0.05 \mathrm{mg} / \mathrm{L})$ in and around the Meerut Road industrial area involving in a number of industrial activities as chrome plating, wood preservative, stainless steel, paints, rubber, dye. The results may be due to the improper treated waste disposal in the area.

\section{Classification of groundwater samples}

Groundwater samples were classified based on $\mathrm{Cl}^{-}, \mathrm{SO}_{4}{ }^{2-}$, and $\mathrm{HCO}_{3}{ }^{-}$concentration as normal chloride $(<15 \mathrm{meq} /$ L), normal sulfate $(<5 \mathrm{meq} / \mathrm{L})$, and normal bicarbonate (2-7 meq/L) water type (APHA 1992; IIED 2002). Based on classification, majority of the groundwater samples are of normal sulfate type followed by normal chloride type and normal bicarbonate type during both the season.
Fig. 5 a Base-exchange indices $\left(r_{1}\right)$ and $\mathbf{b}$ meteoric genesis index $\left(r_{2}\right)$ for the ground water samples of the study area
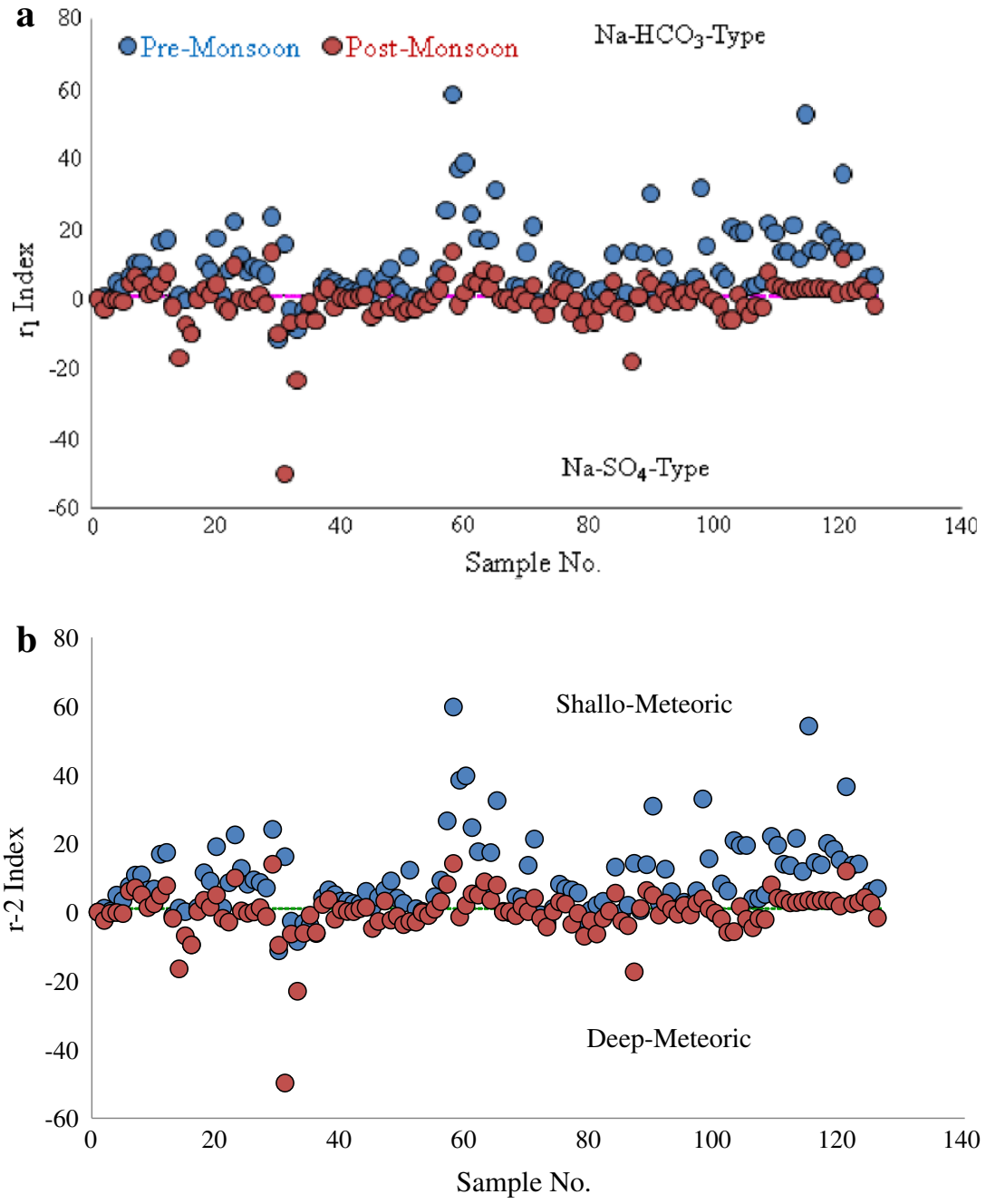
Base-exchange indices

The base-exchange indices for the groundwater resources were determined using Eq. 1 (Matthess 1982) to further classify groundwater

Base-exchange indices $\left(r_{1}\right)=\mathrm{Na}^{+}-\mathrm{Cl}^{-} / \mathrm{SO}_{4}^{2-}$

where $r_{1}$ is the base-exchange index and $\mathrm{Na}^{+}, \mathrm{Cl}^{-}$, and $\mathrm{SO}_{4}{ }^{2-}$ concentration are in meq/L. If $r_{1}<1$, the groundwater sources is of $\mathrm{Na}^{+}-\mathrm{SO}_{4}{ }^{2-}$ type while $r_{1}>1$, indicate the sources to be $\mathrm{Na}^{+}-\mathrm{HCO}_{3}{ }^{-}$type. Based on $r_{1}, 21 \%$ PRE-M samples are categorized as $\mathrm{Na}^{+}-\mathrm{SO}_{4}{ }^{2-}$ type $\left(r_{1}<1\right)$, and $78.4 \%$ samples are $\mathrm{Na}^{+}-\mathrm{HCO}_{3}{ }^{-}$type $\left(r_{1}>1\right)$. On the other hand, in POST-M $56 \%$ of the groundwater samples are classified as $\mathrm{Na}^{+}-\mathrm{SO}_{4}{ }^{2-}$ type $\left(r_{1}<1\right)$ and rest are $\mathrm{Na}^{+}-\mathrm{HCO}_{3}{ }^{-}$type $\left(r_{1}>1\right)$ (Fig. 5a).
Meteoric genesis indices

The groundwater sources can also be classified based on the Meteoric genesis index, and can be calculated using Eq. 2 (Soltan 1999).

Meteoric genesis indices $\left(r_{2}\right)$
$\quad=\left(\mathrm{Ka}^{+}+\mathrm{Na}^{+}\right)-\mathrm{Cl}^{-} / \mathrm{SO}_{4}^{2-}$

where $r_{2}$ is meteoric genesis index and the concentrations of $\mathrm{Na}^{+}, \mathrm{K}^{+}, \mathrm{Cl}^{-}$, and $\mathrm{SO}_{4}{ }^{2-}$ are expressed in meq/L. If $r_{2}<1$, the groundwater source is of deep meteoric water percolation type whereas, $r_{2}>1$ indicates it is of shallow meteoric water percolation type. Based on observations the pre-monsoon season, $19 \%$ of the groundwater samples are deep meteoric water percolation type and $81 \%$ of the groundwater samples are shallow meteoric water
Fig. 6 Chadha's plot showing chemical characteristics of ground water during (a) preand (b) post-monsoon seasons
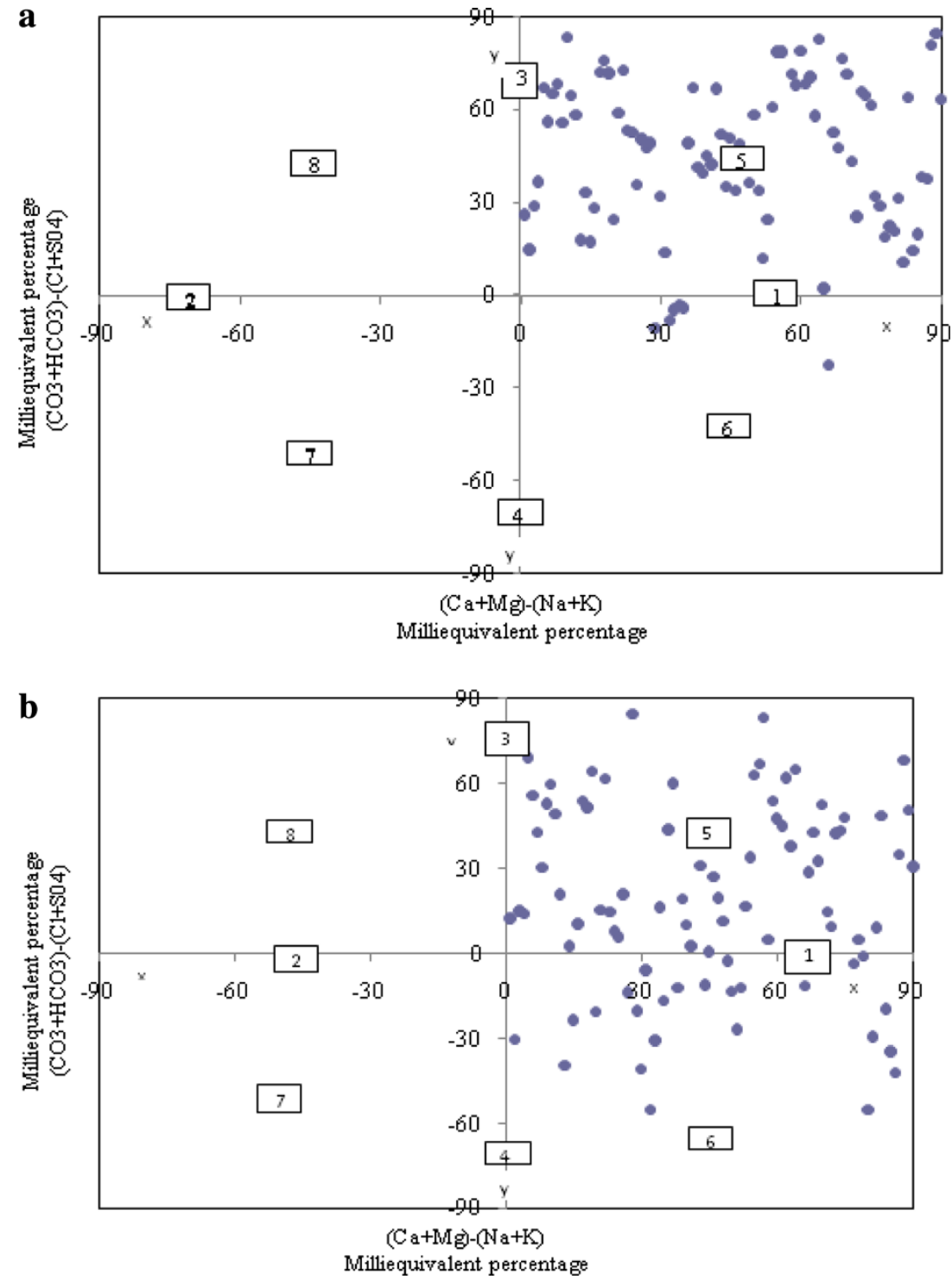

Milliequivalent percentage 
percolation type, whereas, $55 \%$ groundwater samples are deep meteoric water percolation type and $45 \%$ is shallow meteoric water percolation type during POST-M season. Moreover, the groundwater sources categorized as belonging to $\mathrm{Na}^{+}-\mathrm{SO}_{4}{ }^{-}$-type were found belong to the deep meteoric water percolation type (Fig. 5b).

The classification for hydrochemical faces in terms of the major ion percentage and water type, is according to the domain in which they occur on the diagram segment, which is summarized through Chadha's diagram (Chadha 1999) are presented in Fig. 6a, b. This diagram is a modified version of the Piper diagram (Piper 1944) and the expended Durov diagram (Durov 1948). The difference is that the two equilateral triangles are omitted (Dindane et al. 2003; Escolero et al. 2005). In this diagram, the difference in milli-equivalent percentage between alkaline earths metals $\left(\mathrm{Ca}^{2+}+\mathrm{Mg}^{2+}\right)$ and alkali metals $\left(\mathrm{Na}^{+}+\mathrm{K}^{+}\right)$, expressed as percentage reacting values, is plotted on the $x$ axis, and the difference in milli-equivalent percentage between weak acidic anions $\left(\mathrm{CO}_{3}{ }^{2-}+\mathrm{HCO}_{3}{ }^{-}\right)$and strong acidic anions $\left(\mathrm{Cl}^{-}+\mathrm{SO}_{4}{ }^{2-}\right)$ is plotted on $y$-axis. According to Chadha's plot the rectangular field is divided into eight sub-fields, our results clearly show that majority of samples in PRE-M season fall in fifth group which reveals that the alkaline earths and weak acidic anions exceed over alkali metals and strong acidic anions, respectively. This water has temporary hardness. Therefore, the positions of the data points in the proposed diagram represent $\mathrm{HCO}_{3}{ }^{-}$dominant $\mathrm{Ca}^{2+}-\mathrm{Mg}^{2+}$ type waters. On the other hand during POST-M, the maximum number of sample scattered in group fifth and some samples lie in group sixth. The data points shows that the water type is $\mathrm{HCO}_{3}{ }^{-}$dominant $\mathrm{Ca}^{2+}-\mathrm{Mg}^{2+}$ type along with $\mathrm{Cl}$-dominant $\mathrm{Ca}^{2+}-\mathrm{Mg}^{2+}$-type water. The groundwater quality
Fig. 7 a Salinity index and b chlorinity index for the groundwater samples

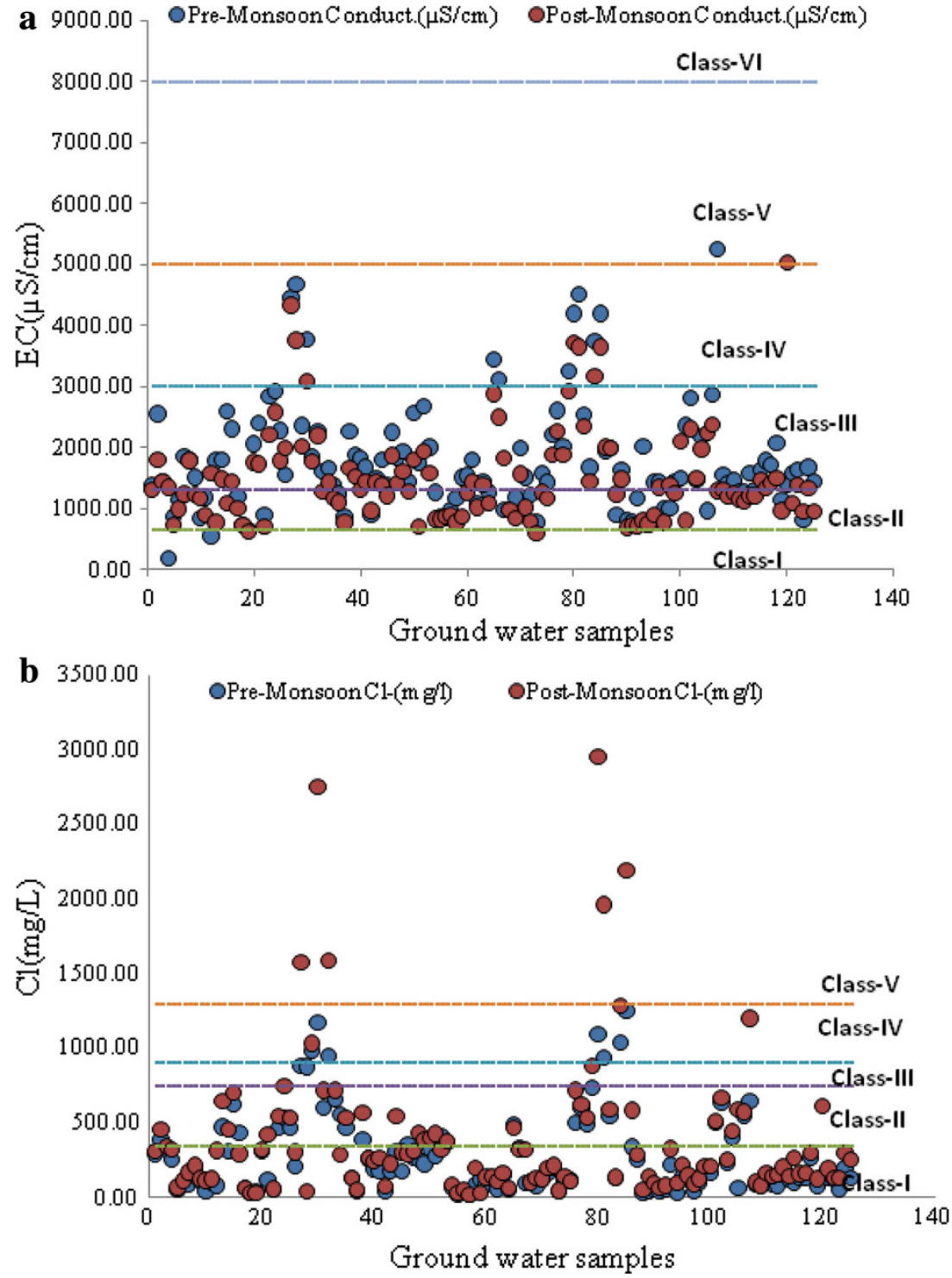


suitability in the study area was evaluated for drinking, domestic and irrigation purposes.

Suitability for drinking and irrigation purposes

The suitability of water samples for drinking and domestic uses were analyzed by comparing different water quality parameters with the standards (Bureau of Indian standard (BIS) 2005). Among PRE-M, 99.20, 97, 39.20, 60, 7.2, 88, $86.4, \approx 10,31.20,6.4, \approx 2,2.4, \approx 41$, and $\approx 9 \%$ and in POST-M 100, 92, 49.6, 56.8, 27.2, 69.6, 83.2, 12, 20.8, 7.2, $0.8,4,69.61,16 \%$ of the groundwater samples violated desirable limit prescribed by Bureau of Indian standard (BIS) (2005) for, TDS, $\mathrm{Cl}^{-}, \mathrm{TH}, \mathrm{Ca}, \mathrm{Mg}, \mathrm{TA}, \mathrm{SO}_{4}{ }^{2-}, \mathrm{F}^{-}$, $\mathrm{Cr}-\mathrm{VI}, \mathrm{NO}_{3}{ }^{-}, \mathrm{Cu}, \mathrm{Fe}$, and $\mathrm{Pb}$, respectively. High level of these parameters in groundwater may lead to unpleasant test and adverse effects on domestic use whereas fluoride and chromium is known to have adverse effect on health. Our results in corroborated with Kumari et al. 2013.
Suitability of groundwater for irrigation purpose can be assessed using the indices for salinity, chlorinity and sodicity (Mills 2003). Salinity index of the groundwater samples were computed using the measured EC values. Water exhibiting low to moderate salinity (classes I and II) are not considered very harmful to soils or crops, whereas, those exhibiting high salinity (class III) are suitable for irrigating the medium and high salt tolerant crops. High salinity water (class IV) is suitable for irrigating high salt tolerant crops, whereas, water of salinity class $\mathrm{V}$ or above is generally unsuitable for irrigation. The total salt content of water gives the salinity and related to EC and TDS values. High concentration of EC and TDS in irrigation water may increase the soil salinity, which affects the plants salt intake. Majority of the groundwater samples about $\sim 90 \%$ in PRE-M and $92 \%$ in POST-M are categorized under class II or III (Fig. 7a). These groundwater samples are showing moderate to high salinity, thus may be considered as suitable for irrigation. Based on the
Fig. 8 a SAR and $\mathbf{b}$ RSC (in $\mathrm{meq} / \mathrm{L}$ ) of groundwater samples during pre-and post-monsoon seasons
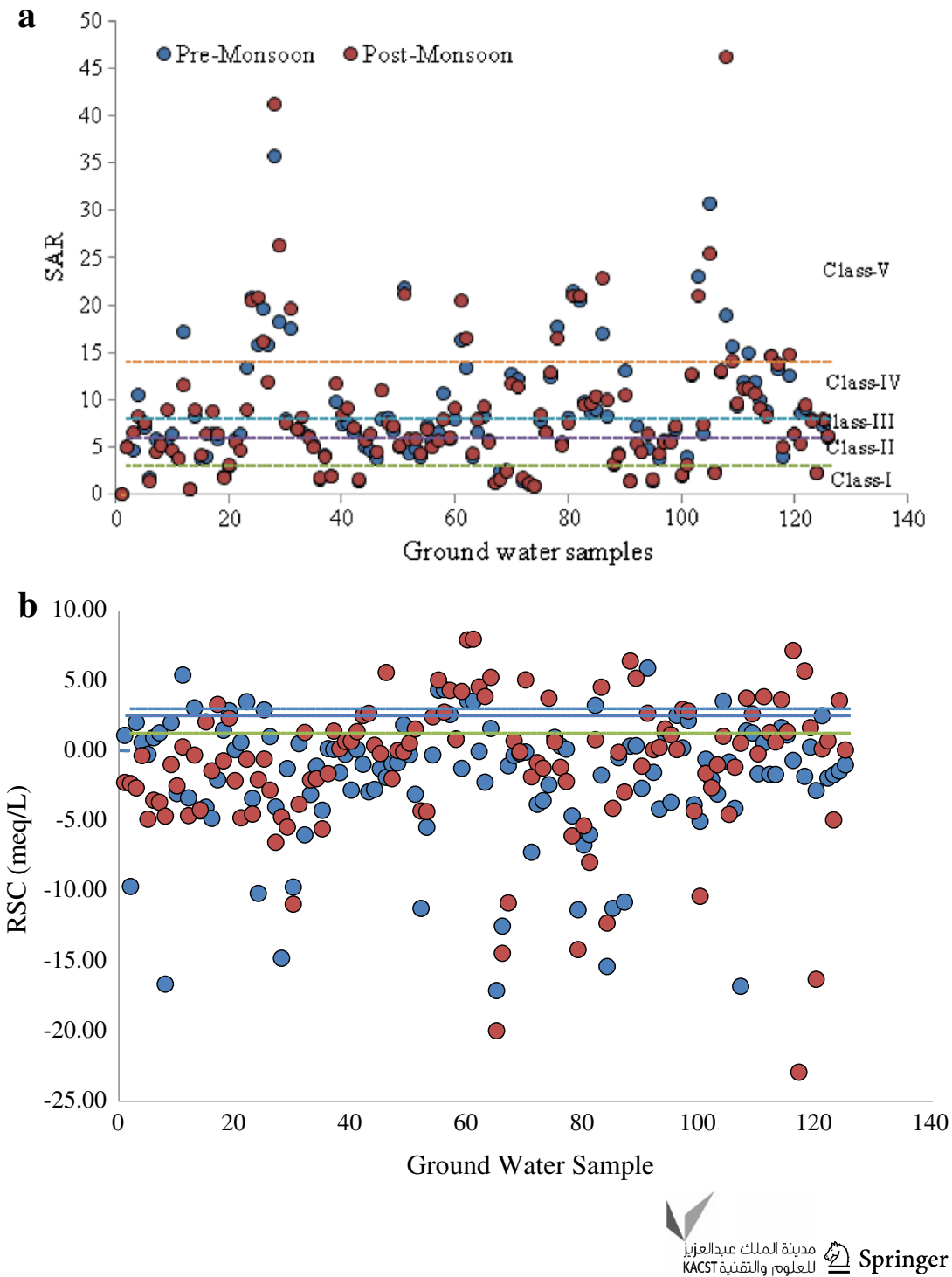
chlorinity index (Mills 2003) majority of the groundwater samples ( $\sim 93 \%$ in PRE-M and $92 \%$ in POST-M season) may be considered suitable (class I, class II) for irrigation (Fig. 7b). Sodicity index (Richards 1954) was calculated using the sodium adsorption ratio $(\mathrm{SAR}), \mathrm{SAR}=\mathrm{Na} /$ $\sqrt{ } \mathrm{Ca}+\mathrm{Mg} / 2$. The $\mathrm{SAR}$ is used to predict the sodium hazard of high carbonate waters especially if they contain no residual alkali. Classification of the groundwater samples based on sodicity index is shown in Fig. 8a. Water up to class II, are generally considered suitable for irrigation. Bi-carbonate and carbonate concentration also influence the water suitability for irrigation purposes. When total carbonate exceeds the total calcium and magnesium concentration in the water quality may be diminish. RSC (meq/L) (Eaton 1950) calculated using the formula $\mathrm{RSC}=\left(\mathrm{HCO}_{3}{ }^{2-}+\mathrm{CO}_{3}{ }^{-}\right)-\left(\mathrm{Ca}^{2+}+\mathrm{Mg}^{2+}\right)$. If $\mathrm{RSC}$ values $<1.25 \mathrm{meq} / \mathrm{L}$, the water is considered to be safe. $\mathrm{RSC}$ between 1.25 and $2.5 \mathrm{meq} / \mathrm{L}$, the water is of marginal quality. If RSC $>2.5$ the water is not appropriate for irrigation. In the present study, RSC values were calculated and shown in Fig. 8b. Figure $8 \mathrm{~b}$ clearly shows that the RSC value in 80 and $68 \%$ samples were $<1.25 \mathrm{meq} / \mathrm{L}$ in PRE-M and POST-M season, respectively. Thus, based on RSC criteria, the majority of groundwater samples can be considered for irrigation purpose which are in agreement with the results obtained by salinity, chlorinity and sodicity indices.

\section{Conclusion and recommendation}

This study provides significant information on groundwater quality in the Ghaziabad Indo-gangetic plain, UP, India. High contents of various physico-chemical parameters viz. $\mathrm{pH}, \mathrm{TH}, \mathrm{TA}, \mathrm{TDS}$, major cations, anions, and heavy metals deteriorated the water quality of the study area, which are influenced by the effluents of industrial, domestic and agriculture sectors. High level of these parameters in groundwater may lead to unpleasant taste and adverse effects on domestic use. The effect of season was not significantly observed in pollution parameters. On the basis of classification, the area water shows normal sulfate, chloride and bi-carbonate type, respectively. Chadda's diagram revealed that the hydro-chemical faces belong to the $\mathrm{HCO}_{3}{ }^{-}$dominant $\mathrm{Ca}^{2+}-\mathrm{Mg}^{2+}$ type along with $\mathrm{Cl}^{-}$dominant $\mathrm{Ca}^{2+}-\mathrm{Mg}^{2+}$-type. Values of the hydro-chemical parameters suggest that the meteoric genesis of these sources was shallow and deep meteoric water percolation type. The quality of groundwater were compared with BIS standards and revealed that the bulk of water samples are suitable for irrigation purpose but not for drinking. If the situation is not control in future, it may assume alarming situation for inhabitants. Therefore, a great attention should be given in order to reduce pollution load especially of chromium, lead, and iron.

Acknowledgments I would like to thank Dr. K.P. Singh Scientist, CSIR-Indian Institute of Toxicology Research, Lucknow, and all the members of Environmental Chemistry Division, IITR, Lucknow.

Open Access This article is distributed under the terms of the Creative Commons Attribution License which permits any use, distribution, and reproduction in any medium, provided the original author(s) and the source are credited.

\section{References}

American Public Health Association (APHA) (1992) Standard method for examination of water and wastewater, 18th edn. APHA, AWWA, WPCF, Washington, pp 90-305

American Public Health Association (APHA) (2005) Standard method for examination of water and wastewater, 21st edn. APHA, AWWA, WPCF, Washington

Ansari AA, Singh IB, Tobschall HJ (2000) Importance of geomorphology and sedimentation processes for metal dispersion in sediments and soils of Ganga plain: identification of geochemical domains. Chem Geol 162:245-266

Bureau of Indian standard (BIS) (2005) Indian standard specification for drinking water. New Delhi, India. BIS publication No. IS: 10500

Chadha DK (1999) A proposed new diagram for geochemical classification of natural waters and interpretation of chemical data. Hydrol J 75(5):431-439

Chae G, Yun S, Kim K, Mayer B (2006) Hydrogeochemistry of sodium-bicarbonate type bedrock groundwater in the Pocheon spa area, South Korea: water-rock interaction and hydrologic mixing. Hydrol J 321:326-343

Dar MA, Shankar K, Dar IA (2011) Fluoride contamination in ground water: in major challenge. Environ Monit Asses 173(1-4):955-968

Dindane K, Bouchaou L, Hsissou Y, Krimissa M (2003) Hydrochemical and isotopic characteristics of groundwater in the Souss Upstream Basin, southwestern Morocco. J Afr Earth Sci 36:315-327

Durov SA (1948) Natural waters and graphic representation of their compositions. Akademiya Nauk SSSR Doklady 59:87-90

Eaton FM (1950) Significance of carbonates in irrigation waters. Soil Sci 69:123-133

Escolero O, Marín LE, Steinich B, Pacheco JA, Molina-Maldonado A, Anzaldo JM (2005) Geochemistry of the hydrogeological reserve of Mérida, Yucatánm, Mexico. Geofís Int 44(3):301-314

Gupta S, Mahato A, Roy P, Datta JK, Saha RN (2008) Geochemistry of groundwater, Burdwan district, West Bengal, India. Environ Geol 53:1271-1282

International Institute for Environment and Development (IIED) (2002) Breaking new ground: mining, minerals and sustainable development. Earthscan Publication, London

Irfan M, Said M (2008) Hydrochemical characteristics and the effects of irrigation on groundwater quality in Harran Plain, GAP Project, Turkey. Environ Geol 54:183-196

Jalali M (2006) Chemical characteristics of groundwater in parts of mountainous region, Alvand, Ha madan, Iran. Environ Geol $51: 433-446$

Jalali M (2007) Assessment of the chemical components of Famenin groundwater, western Iran. Environ Geochem Health 29:357374 
Kolahchi Z, Jalali M (2006) Effect of water quality on the leaching of potassium from sandy soil. J Arid Environ 68:624-639

Kumar M, Kumari K, Singh UK, Ramananthan AL (2009) Hydrogeochemical processes in the groundwater environment of Muktsar, Punjab: conventional graphical and multivariate statistical approach. Environ Geol 57:873-884

Kumari S, Singh AK, Verma AK, Yaduvanshi NPS (2013) Assessment and spatial distribution of groundwater quality in industrial areas of Ghaziabad, India. Environ Monit Assess. doi:10.1007/ s10661-013-3393-y

Matthess G (1982) The properties of groundwater. Wiley, New York

Mills B (2003) Interpreting water analysis for crop and pasture, File No. FS0334. DPI'S Agency for food and fiber sciences, Toowoomba

Pattanayak J, Mondal K, Mathew S, Lalvani SB (2000) A parametric evaluation of the removal of As (V) and As (III) by carbon-based adsorbents. Carbon 38:589-596

Piper AM (1944) A graphic procedure in geochemical interpretation of water analyses. Am Geophys Union Trans 25:914-923

Ravikumar P, Somashekar RK, Mehmood MA (2013) Water quality index to determine the surface water quality of Sankey tank and Mallathahalli lake, Bangalore urban district, Karnataka, India. Appl Water Sci. doi:10.1007/s13201-013-0077-2

Singh KP (1994) Temporal changes in the chemical quality of ground water in Ludhiana area. Curr Sci 66:375-378

Singh B, Jain V, Mohan A (2013) Monitoring of groundwater chemistry in terms of physical and chemical parameters of
Gajraula, a semi-urbanized town of North India. Phys Chem Earth 58:34-41

Sinha PK (1980) Quaternary geology and geomorphology of part of Yamuna Basin, districts, Faridabad, Ghaziabad and Union Territory of Delhi. Prog Rep GSI, 1-30

Soltan ME (1999) Evaluation of groundwater quality in Dakhla Oasis (Egyptian Western Desert). Environ Monit Assess 57:157-168

Srinivasamoorthy K, Vijayaraghavan K, Vasanthavigar M, Sarma VS, Chidambaram S, Anandhan P (2010) Assessment of groundwater quality with special emphasis on fluoride contamination in crystalline bed rock aquifers of Mettur region, Tamilnadu, India. Arab J Geosci 5:83-94

Subba RN (2002) Geochemistry of groundwater in parts of Guntur district Andhra Pradesh, India. Environ Geol 41:552-562

Subramani T, Elango L, Damodarasamy SR (2005) Groundwater quality and its suitability for drinking and agricultural use in Chithar River Basin, Tamil Nadu, India. Environ Geol 47:1099-1110

Vasanthavigar M, Srinivasamoorthy K, Ganthi R, Vijayaraghavan K, Sarma VS (2012) Characterisation and quality assessment of groundwater with a special emphasis on irrigation utility: Thirumanimuttar sub-basin, Tamil Nadu, India. Arab J Geosci $5: 245-258$

World Health Organization (WHO) (2004) Guideline for drinkingwater quality: training pack. WHO, Geneva

Zhang L, Song X, Xia J, Yuan R, Zhang Y, Liu X, Han D (2011) Major element chemistry of the Huai River basin, China. Appl Geochem 26:293-300 